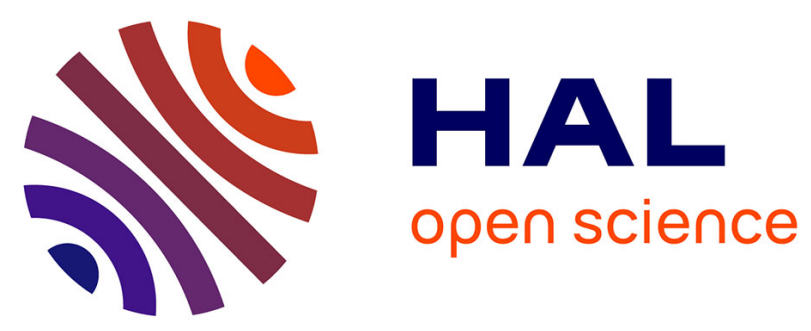

\title{
Comparing local policy practices to implement ICT-based home care services for aging-in-place in Finland, France, Italy, Spain \& Sweden
}

\author{
Siavash Atarodi, Anna Maria Berardi, Anne-Marie Toniolo
}

\section{To cite this version:}

Siavash Atarodi, Anna Maria Berardi, Anne-Marie Toniolo. Comparing local policy practices to implement ICT-based home care services for aging-in-place in Finland, France, Italy, Spain \& Sweden. Gerontechnology, 2019, 18 (2), pp.108-121. 10.4017/gt.2019.18.2.005.00 . hal-02315164

\author{
HAL Id: hal-02315164 \\ https://hal.science/hal-02315164
}

Submitted on 14 Oct 2019

HAL is a multi-disciplinary open access archive for the deposit and dissemination of scientific research documents, whether they are published or not. The documents may come from teaching and research institutions in France or abroad, or from public or private research centers.
L'archive ouverte pluridisciplinaire $\mathbf{H A L}$, est destinée au dépôt et à la diffusion de documents scientifiques de niveau recherche, publiés ou non, émanant des établissements d'enseignement et de recherche français ou étrangers, des laboratoires publics ou privés. 
archives-ouvertes

\section{Comparing local policy practices to implement ICT-based home care services for aging-in-place in Finland, France, Italy, Spain \& Sweden} Siavash Atarodi, Anna Maria Berardi, Anne-Marie Toniolo

\section{- To cite this version:}

Siavash Atarodi, Anna Maria Berardi, Anne-Marie Toniolo. Comparing local policy practices to implement ICT-based home care services for aging-in-place in Finland, France, Italy, Spain \& Sweden. Gerontechnology, ISG International Society for Gerontechnology, 2019, 18 (2). hal-02315164

\section{HAL Id: hal-02315164 \\ https://hal.archives-ouvertes.fr/hal-02315164}

Submitted on 14 Oct 2019

HAL is a multi-disciplinary open access archive for the deposit and dissemination of scientific research documents, whether they are published or not. The documents may come from teaching and research institutions in France or abroad, or from public or private research centers.
L'archive ouverte pluridisciplinaire HAL, est destinée au dépôt et à la diffusion de documents scientifiques de niveau recherche, publiés ou non, émanant des établissements d'enseignement et de recherche français ou étrangers, des laboratoires publics ou privés. 


\title{
S. Atarodi, A.M. Berardi, A.M. Toniolo
}

\section{Comparing local policy practices to implement ICT-based home care services for aging-in-place in Finland, France, Italy, Spain \& Sweden}

\begin{abstract}
Background. The current aging of the population across Europe is creating multiple challenges to the European states as well as to the European authorities. They have to design and implement sustainable policies for aging-in-place (for home care services for the elderly) to improve their wellbeing and inclusion in the information society. So far, several European initiatives have been runned to bring answers and solutions.

Research aim. The aim of this paper is to understand wether and how several local authorities in the European Union build regulations and strategies for the ICT-based home care services intended to the elderly and where they stand regarding the literature's recommendations.

Method. We focus on the results of the SILHOUETTE project, that was part of CREATOR, an INTERREG-IV C mini-programme. We particularly focus on the public policy practices for the development of the ICT-based solutions for aging-in-place (home care services for the elderly) that the project identified. This paper is an analytical and comparative synthesis of these data in relation to the scientific literature. Public policy practices have been compared across territories of seven European countries.
\end{abstract}

Results. We found that the seven regions are at different levels of maturity of public policy practices and that the SILHOUETTE project succeeded to enlighten different ways to boost the implementation of ICT-based solutions.

Discussion. From this comparison we built a table showing the integrated stages of local strategies' development. Comparison with the literature showed a greater development of Nordic countries, with the Finnish region being the only one whose guidelines included a great number of recommendations. Moreover, in this sector, the East/West gap is less present than in the global long-term care services sector and studies from other regions of the world can be useful for European stakeholders.

Keywords: Elderly care, E-inclusion, Public policy, INTERREG project, Ambient Assisted Living

\section{INTRODUCTION}

The increasing number of elderly in the European population is a challenge for the social organization and internal cohesion of the European Union (Giannakouris, 2008 ; Cavallo, Pujol, 
Garcia and Dario, 2010 ; Coenen, Hansen and Rekers, 2015). Since the years 2000s several Initiatives have been launched to face it (Wintlev-Jensen, 2010 ; Cavallo et al., 2010 ; Gorman, Mikalsen, Stav and Walderhaug, 2010 ; Knapp et al., 2010 ; Olsson, 2010). Also, the European Commission has decided to direct all of its member states, at the continental level, to a set of common policies and guidelines including, for instance, a framework for quality labeling and certification of e-health for active and healthy aging (see the Second European Demography Forum, 2008 and The European Commission, 2011, 2012).

To organize such level of cooperation and achieve these objectives, the first steps are to list identify, assess and compare existing practices (European Commission, 2011; Le GoffPronost and Picard, 2011; Atarodi et al., 2012, Vimarlund and Olve, 2015). In the case of care and assisted living services for the elderly, this type of study is not only rare but also limited, either in geographical terms or in thematic terms (Costa-Font et al. 2008, Pavolini and Ranci 2008, Österle 2010, Riedel, Kraus and Mayer, 2015).

The present paper focuses on the identification and comparison of the regulations and public policy practices governing the relationship between supply and demand for ICT-based home care services to the elderly. Home care has been defined by the Organization for Economic Co-operation and Development (OECD, 2005) as formal care by organizations in the beneficiary's home in relation to day-to-day functioning, such as personal care (eating, bathing, dressing), housework, nursing and social services. ICT-based services are the ones delivered or accessed through an ICT device or network (Damant, 2014). We are particularly interested in the regulations and public policy strategies at regional and local levels designed to enhance the aging-in-place in European Union (EU).

\section{Related literature}

The present paper is in line with the literature regarding the long-term care systems for the elderly. Previous studies on this subject addressed funding issues (Karlsson, Mayhew and Rickayzen, 2007; Fernandez, Forder, Trukeschitz, Rokosova, and McDaid, 2009; Costa-Font and Courbage 2012), cash-for-care and cash benefits schemes (Timonen, Convery, and Cahill, 2006; Da Roit Le Bihan, B. and Österle 2007; Arksey and Kemp 2008; Da Roit and Le Bihan 2010), patients' rights (Le Bihan and Martin 2006) and reforms of the long-term care systems (Pavolini and Ranci 2008; Glendinning and Moran 2009; Österle 2010; Rostgaard 2011; Simonazzi 2012)

However, a combined overview, as a whole, of long-term care systems' features for the elderly has not been carried out before Riedel, Kraus and Mayer (2015). This research is the first to address the question of long-term homecare organization and supply for this specific population. It is also the first to include old and new EU member states in the comparison (Riedel, Kraus and Mayer, 2015). Based on national public policy documents from 2010 in 21 European countries, the organizational aspects of formal home care service for the elderly over 65 were compared to provide an understanding of how care is accessed. The study consisted of a description of the forms of organization and regulation of home care supply by attempting to answer three hypotheses. Thus, the authors showed that: (1) the regulation of home care for the elderly was more centralized in the new member countries of the EU from Eastern Europe than in the former member states; (2) access to this type of service was not more difficult in the new member countries because of lower economic performance. In other words, the income and disability conditions regulations required to obtain services were not 
more restrictive; (3) in Eastern European countries formal and regulated home care was less developed than in western and Scandinavian countries. Eastern European countries were more accustomed to the either institutional care or informal caregiving by relatives, but not to an organized system of institutional care at home, which does mean that their capacity to offer homecare services was lower.

So far, the ICT-based homecare services' regulations and organizations have not been included in comparative studies at an intra European scale (Riedel, Kraus and Mayer, 2015). However, ICTs can be used to overcome some of the existing problems of care systems, especially the challenges related to population aging (Cartwright et al., 2013; Damant et al., 2013). An exploratory seminar organized in 2010 under the auspices of the European Science Foundation and bringing together 23 researchers from 15 countries identified the following research areas to facilitate the use of ICTs in medical and social care: (1) identification of available information, and communication needs in relation to different use scenarios at the intersection between health and social care, (2) development and mapping of shared ontologies and standards for integration and/or brokerage; (3) sharing and accessibility of information, enabling to develop a trust system where the patient is an active partner and where policies are established considering all partners and interests, (4) analysis of the use of automatic and intelligent knowledge-based and context-relevant services, and (5) empowerment of citizens (or selected representatives) to become co-producers through modern IT (Information technology) tools, while carefully avoiding the marginalization of the most vulnerable (Rigby, Hill, Koch and Keeling, 2011).

Such a study of national public policies for ICT-based home health care services for the elderly has been completed in Japan (Abraham et al., 2011). This study, conducted through interviews with relevant sector's stakeholders and the analysis of public strategy documents, has shown that despite institutional efforts at the national level to both promote and regulate the formats and protocols of ICT-based care services, refinement and clarification of public strategy remained necessary. According to these authors, the new directions to be developed would concern: (a) the training of ICT specialists within the medical community, (b) incentives for service providers, (c) legislation dealing with responsibilities, security, privacy and confidentiality; (d) the inclusion of stakeholders in the development of solutions; and (e) the creation of sustainable business models.

\section{Research purpose}

We are seeking to know whether ICT-based services intended to enhance aging-in-place are subject to specific public measures, at regional and local levels in EU member states, as they relate to the conditions to be met by service providers, by commercial and industrial entities and by the beneficiaries. We also seek to know whether public fundings exist and under what conditions they are attributed, as well as whether public-private partnerships are found, and if public initiatives to facilitate and promote access to such services exist.

In the present paper we analyze the regulations and strategies relative to the use of ICTbased home care services for aging-in-place as identified and reported in the SILHOUETTE (uSIng noveL information tecHnOlogies for the sUpport of Elderly's acTive parTicipation in the information sociEty) project between 2011 and 2013 (creator7.eu/sub-projects-2/silhouette). SILHOUETTE was a subproject of CREATOR, an INTERREG-IV C cooperative mini-programme (creator7.eu/creator-mini-programme). To the best of our knowledge this is the first and, to 
the present day, the only project that has gathered data from several EU member states on this topic at regional and local levels. Within its frame, public policy practices of seven european territories have been described in order to collect information and highlight the best practices. However, the project does not intend to: (1) compare the data collected to the scientific literature's recommendations, i.e. to evaluate the possible gaps between policy practices and recommendations and, (2) compare the nature of possible gaps between the different territories' data.

In the present paper, our goal is to carry out a comparative analysis of the identified practices across the seven regions and territories studied: Asturias (Spain), Brescia (Italy), Kanta-Häme (Finland), Lorraine (France), North Hungary (Hungary), Västerbotten (Sweden) and Wielkopolska (Poland). We sought to describe the similarities and differences between regions because of their specific initiatives and policies and to compare them to the relevant literature in order to identify the gaps between actual practices, as derived from the only project that focused on this subject within the EU and from the literature's recommendations. Therefore, the present work is a perspective-taking analysis of the SILHOUETTE project's results in light of the literature.

We also aim to come up with recommendations about what can be tackled by regional and local governments depending on how big is the gap, in each territory, to reach the scientific literature recommendations. Our step-by-step recommendations will be useful not only to the studied territories, but also to all the territories whose strategies are similar to those analyzed in our paper.

\section{METHOD}

An identical methodology was applied across the seven territories studied. Documents relating to policies, regulations and legislation as well as information documents intended for the general public (websites, official brochures of social administrations, as well as service and care providers) were identified and analyzed by teams from each of the regions within the framework of the SILHOUETTE research project from 2011 to 2013. Press articles reporting on ICT use by the elderly in these regions or concerning the ICT sector in relation to the elderly at regional or local levels have also been sought. Relevant excerpts from each region's documents were translated into English by the research teams for sharing. All the data have been included in the reports published on silhouette-project.eu, the SILHOUETTE project website now inactive (Arenghi, Angelini \& Pucci, 2012; Atarodi, Berardi \& Pruski, 2011 ; Fundacion CTIC, 2011 ; Gluszak, Kosiedowski \& Minkowski, 2011 ; Gyorffy, Nagy \& Nandori, 2011 ; Piironen, 2011 ; Umea University, 2011). The data presented here are therefore available in these reports. The French Region's data are the only ones collected by the authors of the present paper. This paper is an analytical and comparative synthesis of these data in relation to the scientific literature currently available. The information provided in the reports regarding the long-term care systems in the countries, for instance the structuring of health care systems or the authorities in charge of providing the services, have also been included in the present paper. For more information regarding this topic in EU member states see Riedel, Kraus and Mayer (2015). 


\section{DATA}

Public policy practices have been identified in five out of seven territories, while Brescia (Italy) and North Hungary have none. We detail them below by region. The analysis and the catagorizations of the ICT-based services and strategies developed in this section are from the authors of the present paper. This analysis shows how practices and means to approach this subject tend to vary widely accross the observed territories.

\section{Lorraine Region - France}

In France, healthcare strategies and assistance services for the elderly persons suffering from loss of autonomy are governed by national legislation. Supervision of the functioning of the services and their organization is carried out at the regional level through the Regional Health Agency. The management of the services provided to the elderly is carried out by the County Councils (Conseil Départemental in French) as well as by the municipalities and intercommunalities (Atarodi, Berardi \& Pruski, 2011). These authorities have a freedom to develop specific policies at their own level within the national legislation boundaries. Five public strategies that promote the use of ICT-based solutions for the support of the elderly's autonomy have been identified. The first three strategies have been identified by Atarodi et al. (2011), while the last two, presented below, have been added to this paper. We present them in this section.

\section{The Personalized Allowance for Autonomy}

A policy under national legislation has been identified as promoting the use of ICT-based services to the elderly: the Personalized Allowance for Autonomy (APA). This allocation was not created for this purpose, but it is mainly this scheme that allows the diffusion of ICTs for the elderly in Lorraine and France. The APA was created to provide financial assistance to the elderly who can not live independently and / or need ongoing support to carry out activities of daily living. The allowance is granted to persons aged 60 and over, living at home or in retirement homes, with the same criteria throughout the country (depending on income and degree of dependence) and is managed by the counties. It can be used to finance services such as home help, day care, temporary accommodation, but also technical aids or adaptation / improvement of housing conditions, including the adoption of assistive ICTs. These services can be supported by the APA provided that their suppliers are professional organizations or associations approved by the Prefecture of each county to perform a living assistance activity. The decision to offer ICT-based solutions is therefore that of service providers and product suppliers.

Teleassistance service subsidy

A second policy identified in the French Region is also an allowance. The city of Metz has decided to pay a minor part of the monthly subscription fees for each elderly person living in Metz who has subscribed to the Mosellane Association of Assistance for the Elderly's (AMAPA in French) teleassistance service, a remote assistance available every day at any time by simply pressing a warning button located on a pendant or bracelet. The amount of this allowance is fixed and identical for each subscriber. 


\section{Introductory computer courses}

The third policy identified is the promotion and organization of introductory computer courses for the elderly. Since 2010, the Meurthe-et-Moselle County has undertaken the organization of such courses through the transversal collaboration between the county's elderly-handicapped persons division, the county's digital development department mission, the college service that makes available computer rooms of the county and the Committee of Representatives of the Elderly (CODERPA in French) which relays information and encourages older people to participate. CODERPA explains that the purpose of these courses is to increase the elderly's use of ICTs at home: "The fight against the physical and moral isolation of the elderly must remain a priority. But ICTs help to break this loneliness to the extent that they promote exchanges " (Living Meurthe-et-Moselle, County Council Magazine, May 2013).

\section{Limiting the risk of fall}

The Vosges County decided in its "disability and lifelong dependency scheme" to encourage the possibility of using ICT-based services to cope with the risk of falls in the elderly: " In addition to housing development, the question of safety can arise: falls are more frequent among the elderly who also have difficulty getting up. The physical and psychological consequences of a prolonged stay on the ground without the possibility to recover or to call a third party for help are heavy. (...) Taking into account new technologies should be studied, to limit this risk, where possible " (Vosges' County council, 2009).

\section{Information sharing}

The same county also proposed "to study the modalities and feasibility of sharing information through the use of new technologies and the use of a single website. As part of an action of pooling resources, improving coordination and better the accessibility for the general public and the readability for professionals, under dedicated centers for older people or people with disabilities " (Vosges' County council, 2009, page 33).

We see that, along with a national allowance program to support products and services acquisition by the elderly for autonomous living, two of the four counties included in this study as well as one city, the regional capitol, have started to build policies at their scale (Table 1). These policies' landscape is heterogeneous and addresses all the policies categories we considered in our analysis. 
Table 1. Synthesis of policy practices in the Lorraine region in France

\begin{tabular}{|c|c|c|c|c|}
\hline & $\frac{\text { Geographical }}{\underline{\text { scale }}}$ & Location & Plan / Strategy title & Category \\
\hline 1 & National & $\begin{array}{l}\text { The entire French } \\
\text { state }\end{array}$ & $\begin{array}{c}\text { The Personalized Allowance for } \\
\text { Autonomy }\end{array}$ & All categories \\
\hline 2 & Municipal & Metz municipality & Teleassistance service subsidy & Health safety \\
\hline 3 & County & $\begin{array}{l}\text { Meurthe-et-Moselle } \\
\text { County }\end{array}$ & Introductory computer courses & $\begin{array}{c}\text { New } \\
\text { communications }\end{array}$ \\
\hline 4 & County & Vosges County & Limit the risk of fall & Health safety \\
\hline 5 & County & Vosges County & Information sharing & All categories \\
\hline
\end{tabular}

\section{Region of Asturias - Spain}

In Spain the regional governments are in charge of social policy and strategies for the elderly's quality of life in the framework of national and European guidelines. In the region of Asturias, three regional ministries have included ICTs in their strategy of supporting the elderly. The Regional Ministry of Social Welfare and Housing is the most involved. It established a regional plan for social inclusion in Asturias, as well as a strategy to promote active aging in the region, both of which include ICTs. The other ministries are the Public Administration, which produced a "Strategy eAsturies 2012", and the Ministry of Health Services, who put in place a "plan for modernization of health services" (Fundacion CTIC, 2011).

The region is made up of 78 municipalities, without county subdivisions. Each municipality promotes various local initiatives through its Municipal Social Service Center, but initiatives are often similar from one municipality to another. The local health care plan of the City Council of Gijon is used as a representative example. In total, five strategies including ICTs for elderly care and services have been identified. Table 2 shows their breakdown by pilot organization.

Table 2. Synthesis of public strategies identified in Asturias in Spain

\begin{tabular}{|c|c|c|c|c|}
\hline & $\frac{\text { Geographical }}{\text { scale }}$ & Location & $\underline{\text { Plan / strategy title }}$ & Category \\
\hline 1 & \multirow{5}{*}{ Asturias region } & \multirow{5}{*}{ The whole region } & $\begin{array}{l}\text { Regional plan for social inclusion in } \\
\text { Asturias 2009-2011 }\end{array}$ & $\begin{array}{c}\text { New } \\
\text { communications }\end{array}$ \\
\hline 2 & & & $\begin{array}{c}\text { Strategy to promote active aging in } \\
\text { Asturias }(2009-2011)\end{array}$ & Out of home support \\
\hline 3 & & & Strategy eAsturias 2012 & $\begin{array}{c}\text { New } \\
\text { communications }\end{array}$ \\
\hline 4 & & & $\begin{array}{l}\text { Modernization plan of health } \\
\text { services in Asturias 2009-2011 }\end{array}$ & Health safety \\
\hline 5 & & & Local plan for healthcare & Health safety \\
\hline
\end{tabular}




\section{Strategy eAsturies 2012}

This general strategy aims to develop the information society in Asturias, defining the strategies and general approaches to achieve the objectives that have been set. Two measures are of particular interest to us:

1) E-Inclusion strategy: Stimulating the active participation of people at risk of digital exclusion from the information society: for "Older people: the implementation of awareness-raising and dissemination of training actions for the use of ICTs and new eservices will be promoted by encouraging active aging through the use of ICTs. The intervention is envisioned in their environment, understood as the sum of the network of family and social agents present in their environment. "

2) E-Health strategy: Care services through advanced ICT (teleassistance): "This practice is particularly important when talking about elderly people, people who are dependent, or people living in rural areas who have great difficulty in receiving care."

Regional Plan for Social Inclusion in Asturias 2009-2011

This document focuses on measures related to exclusion / inclusion. It also includes a diagnosis of poverty and social exclusion. One measure is of particular interest to us within its guideline " Offsets for people at risk of exclusion »: Prevention of exclusion and strengthening of the social participation of the elderly, which says: "Development of programs bringing new technologies closer to the elderly in collaboration with the network of telecentres. "

Strategy to promote active aging in Asturias (2009-2011)

This document aims to promote active and healthy lifestyles among older people by facilitating individual and collective well-being. One measure caught our attention within the scope of action "Social Participation of the Elderly"; that is to "Facilitate the access of the elderly to new technologies and social networks".

\section{Asturias Health Services Modernization Plan 2009-2011}

This document describes a strategic framework for modernizing health services in Asturias in the face of the challenges identified in the stated goal of maintaining a high level of equity and quality in access to health services. One goal mentioned in this document has particularly caught our attention in strategy entitled "Promoting the development of eHealth"; that is: "Promoting telemedicine (for chronic diseases, home care) and eHealth websites (for users and health professionals) ".

Local plan for health care in Gijon

The City Council of Gijon City describes in this document a local plan for health care focusing on the priorities, objectives and measures necessary to meet society's needs. The document includes a priority entitled "Natural evolution of the population" aiming to "improve home care and remote support resources and the quality of (professional) care and their control." 
This last policy is the only one identified at the local level. The first four are all regional policy programs designed to potentially help every elderly in the region. Interestingly, these regional plans complement each other, according to our study's point of view, by covering all of our analysis categories.

\section{Kanta-Häme Region - Finland}

In Finland, public strategies for the elderly are under the responsibility of the Ministry of Health and Social Affairs at the national level. The regional executive makes local adaptations of the national strategies while the health and care services are organized by the municipalities. Thirteen official public documents of strategies including ICTs in the services for the elderly have been identified (Piironen, 2011). Only one of these documents is a publication of the regional executive: "Kanta-Häme Wellness Strategy 2015". The others come from the municipalities and two of the three county executives existing in this region. Table 3 provides a summary of existing strategies, including their geographic scale, location, title and theme.

Table 3. Synthesis of policy strategies in the Kanta-Häme region (Finland)

\begin{tabular}{|c|c|c|c|c|}
\hline & $\begin{array}{l}\text { Geographical } \\
\text { scale }\end{array}$ & Location & Plan / Strategy title & Category \\
\hline 1 & Kanta-Häme region & The whole region & $\begin{array}{l}\text { Kanta-Häme Wellbeing } \\
\text { strategy } 2015\end{array}$ & All categories \\
\hline 2 & \multirow{4}{*}{$\begin{array}{l}\text { Hämeenlinna } \\
\text { County }\end{array}$} & \multirow{3}{*}{$\begin{array}{l}\text { Hämeen-linna } \\
\text { municipality }\end{array}$} & $\begin{array}{l}\text { Strategy of service and } \\
\text { procurement of } \\
\text { Hämeenlinna }\end{array}$ & Communication \\
\hline 3 & & & $\begin{array}{l}\text { Service order policy } 2010-2013 \text { by } \\
\text { the aged people committee }\end{array}$ & Health safety \\
\hline 4 & & & $\begin{array}{l}\text { Service order policy } 2010-2013 \text { by } \\
\text { the wellfare and health committee }\end{array}$ & Health safety \\
\hline 5 & & $\begin{array}{l}\text { Janakkala } \\
\text { Municipality }\end{array}$ & $\begin{array}{l}\text { Municipality elderly care service } \\
\text { plan 2008-2016 }\end{array}$ & Health safety \\
\hline 6 & \multirow{4}{*}{ Forssa County } & \multirow{3}{*}{ The whole county } & $\begin{array}{l}\text { Wellbeing cluster strategy 2008- } \\
2013\end{array}$ & All categories \\
\hline 7 & & & Elderly care policy in Forssa area & Health safety \\
\hline 8 & & & $\begin{array}{l}\text { Forssa Area Joint Municipal Health } \\
\text { Care strategy 2004-2010 - } \\
\text { updated until 2015 }\end{array}$ & Health safety \\
\hline 9 & & $\begin{array}{c}\text { Ypäjä } \\
\text { Municipality }\end{array}$ & $\begin{array}{l}\text { Elderly care Strategy and service } \\
\text { structure development until } 2015\end{array}$ & Health safety \\
\hline 10 & \multirow{4}{*}{ Riihimäki County } & \multirow{2}{*}{ The whole county } & $\begin{array}{l}\text { Healthcare strategies for the } \\
\text { elderly until } 2015\end{array}$ & Health safety \\
\hline 11 & & & $\begin{array}{l}\text { Strategy for dementia care 2008- } \\
2015\end{array}$ & Health safety \\
\hline 12 & & $\begin{array}{l}\text { Riihimäki } \\
\text { Municipality }\end{array}$ & $\begin{array}{l}\text { Municipality's service strategy } \\
2006-2015\end{array}$ & Communi-cation \\
\hline 13 & & Loppi Municipaliy & Elderly care strategy $2010-2020$ & Health safety \\
\hline
\end{tabular}


An analysis and classification of the 13 strategies in six themes was carried out by us. The six themes we have identified are: (1) the well-being of residents, (2) municipal services, (3) municipal strategies for the care of the elderly, (4) county level care strategies for seniors, (5) municipal health care, and (6) dementia. Below we classify the policy documents by topic and detail how ICTs are included within them. We start with public wellfare strategy documents that set out principles and guidelines for a vision, missions, methods, goals, and success factors for wellfare development.

\section{Public welfare strategies}

\section{Kanta-Häme Wellbeing strategy 2015 (the whole region)}

This first document, from the regional government, provides overall guidance for the use of ICTs to improve the elderly's comfort. It recommends using « New modes of operation and new technologies (...) in the production of wellbeing services " and encourages supporting the elderly living at home " in many ways through the use of ICT and wellbeing technology ».

\section{Wellbeing cluster strategy 2008-2013 (Forssa County)}

The second document presents the Forssa area wellbeing cluster strategy, which is "to enhance the wellbeing of its citizens and the environment through versatile, good quality and affordable wellbeing services through improving its operations, supporting technologies and process". It is more specific than the previous document, indicating three objectives regarding ICT-based solutions. The first one is to play a role in different phases, namely the development, deployment, distribution of solutions. Thus, the document emphasizes on the county's involvement in the introduction, testing and maintenance of new ICT-based services and the measurement of the quantity of new services. The second one is to improve the stakeholders' skills "regarding wellbeing technologies". The third objective is to "Increase customer rights and possibilities for choice", particularly by "enhancing utilization of wellbeing and gerontechnologies".

\section{Policy Strategies for Municipal Services}

Public service development strategy documents define the framework, the organization of municipal service structures, the missions, methods, objectives and success factors of municipal services.

\section{Strategy of service and procurement of Hämeenlinna (Hämeenlinna municipality)}

Regarding ICT-based services this document highlights the fact that "Customers are more and more often served through other media than face-to-face contact and therefore the role of email, phone and social media in customer service will increase" which makes it possible for the Hämeenlinna municipality "to provide equal opportunities for its citizens to reach public services" and argues that in the future "The development of technology will change the ways of working and offer possibilities to increase customer focus and productivity". 
Municipality's service strategy 2006-2015 (Riihimäki Municipality)

With this document, the Riihimäki Municipality shows its concern regarding the "Change in the population age structure" and its interest for the "Development of technology that improves service production".

We notice that these two documents focus on the accessibility of municipal services for the elderly through ICTs. Therefore, they do not concern the provision of services specifically dedicated to the elderly which are dealt with in the documents described in the following section.

\section{Strategies for Municipal Elderly Care Services}

Public policy documents for the development of municipal elderly care services are guides to developing elder care that assist with decision-making and planning. They define the organization and structure of services, supplies and investments and plans for the development of services for the elderly.

Service order policy 2010-2013 (senior citizen's advisory council, Hämeenlinna municipality)

The Hämeenlinna municipality's senior citizen's advisory council places among its futures objectives "living safely at home longer" for aged people and "utilization of technology", namely the objectives number 3 and 5 in this document. Also, this committee states that "At the same time when the number of aged people cared in facilities decreases, the services provided for the elderly at home increases" and suggests to try "using the technical opportunities supporting longer and safer living at home." To that end, it defines a concrete way in the short-term: "During the current services planning season, the orderer will follow the development of new technologies and will pilot the most promising ones on a needs' basis. The aim is to bring these technologies as a part of the day-to-day living of aged people and day-to-day work of the care personnel. In the beginning of the planning season, the orderer will study possibilities in the interactive wellbeing-TV for home care customers".

Municipality elderly care service plan 2008-2016 (Janakkala Municipality)

As in the previous document, a priority stated in this one also is "Living at home (...) for the elderly" and proposes "the use of technology in home care services" as a "mean of achieving the objective". It also proposes to use the "development of the content of digital customer information systems" to maintain "continuance of customer care" as a feature of "efficient service processes and way of working".

Elderly care Strategy and service structure development until 2015 (Ypäjä Municipality)

This document recommends "taking into account wellbeing technologies in residency construction projects". Here, interestingly, the use of "wellbeing technologies" for "residency" is presented as a goal, and not as a mean as it was in the Janakkala's document.

Elderly care strategy 2010-2020 (Loppi Municipaliy)

Loppi Municipality's Elderly Care Strategy includes the "use of new technology" among "actions" to reach the "Strategic objective" of "Allocation of resources". It plans the "deployment of one new technology per year".

We notice that these municipal documents dealing with services for the elderly are setting objectives for the deployment and implementation of ICTs in concrete domains (e.g. 
housing) citing concrete ICTs (for example interactive TV) that are sometimes quantified (for example " a new ICT per year »).

\section{County Strategies for Seniors' Care Services}

Strategy documents published by counties provide a basis for planning the care of the elderly by the municipalities, particularly on matters common to all municipalities. Two counties published such documents: Forssa and Riihimaki.

\section{Elderly care policy in Forssa area (Forssa County)}

The Forssa County Elderly Care Policy designates the municipalities, the Forssa Area Joint Municipal health Care (FSTKY) and the Electronics Center of Expertise (InnoForss) as responsible bodies "developing wellbeing technologies" by "testing and innovating on new equipment and methods". A specific aim is to "harmonize the patient information system". The county considers "Possibilities for the deployment of remote workstations and medical reports should be studied in the elderly home care services".

\section{Healthcare strategies for the elderly until 2015 (Riihimäki County)}

The Riihimaki County has the purpose of developing and deploying "Technologies and aids that support independence". The county notices "Customer based electronic document systems are functioning and well used in the region", and plans to develop "new digital service concepts for customer service, communications and feedback gathering".

\section{Public Strategies on Dementia}

A public strategy promoting the inclusion of ICTs in dementia care has been identified in Riihimäki County. It defines basic care for people with dementia. It states as "Critical success factors: supporting living at home, new technologies and aids should be used in the development of home care services. It should be "good quality and cost-effective services [enabling] 24h (e.g. carpets with an alarm, door alarms, etc.) monitoring".

We notice that these three documents are oriented towards research and development activities. The involved counties have been planning to develop new ICT-based solutions for use by stakeholders and / or the elderly themselves. This would be less about improving existing solutions than about operating innovation.

Public Strategies for Municipal Health Care

Public policy documents for municipal health care define service structures, operations, purchases and investments, and development plans for medico-social services. Two documents are presented here.

Service order policy 2010-2013 by the welfare and health committee (Hämeenlinna municipality)

This document presents the plan of "deployment [of a] chronic Care Model" by the "basic health care unit". In this framework "new IT-services targeted to the patients are deployed" leading to solve "Most of the contacts made by the citizens either through phone or remote IT contacts". The Hämeenlinna municipality's welfare and health committee states that "At the moment the use of IT systems remotely is not secure. During this planning season the security of remote IT-usage will be enhanced to enable increased benefits for the 
patients". This committee argues that "The increase in the number of aged people and the variable services demanded by them, will increase the need for geriatric services. It makes sense to offer some of these health services through the home service unit".

Forssa Area Joint Municipal Health Care strategy 2004-2010 - updated until 2015 (Forssa County)

In this document the Forssa County states "wellbeing technology will be used [to enhance] the competence, renewal and wellbeing of the healthcare personnel".

These two documents reveal the will to use ICTs during health care benefits to improve the care, well-being of the beneficiaries and the working conditions of the staff. We also found a concern for the improvement of ICTs especially in terms of data security.

In the Finnish region we notice a great involvement, although not systematic, of local authorities. Only one identified policy practice was designed by the regional council (KantaHäme Wellbeing strategy, 2015) and includes all of our analysis categories. Counties and municipalities designed the other policies with a permanent emphasis on health safety.

\section{Västerbotten Region - Sweden}

In Sweden the responsibility for health care is shared between the state, the region and the municipality. The state is responsible for the overall health policy. The region is responsible for the management of public health and medical care and the municipality is in charge of the care and support services for the elderly outside of hospital (Umea University, 2011).

According to Umea University (2011), in the Västerbotten region, most care services already rely heavily on everyday ICTs. The plans and programs to introduce ICTs have already been successfully implemented and new strategies are no longer designed by local authorities and are no longer considered as in need of local authorities' support. Consequently, at the time of writing this report there is no particular strategy to introduce or implement in ICTbased services for the elderly (Umea University, 2011). Existing ICT-based solutions concern health and safety as well as social inclusion. Some of them are intended to be used by the elderly themselves (such as more or less sophisticated devices of remote alarm or social networks in adapted lines) while others are intended for the professionals in contact with the elderly, such as electronic medical records :

"As a way of trying to foresee and resolve the problems related to increased demands and to give equal access to health care services in northern Sweden, the County of Västerbotten has been focusing on developing telemedical applications. The County council has been working with telemedicine since the late 1990's and has developed many successful telemedical applications that have increased access to healthcare services, especially in the rural areas of Northern Sweden. Today, e-health services are well established in Västerbotten and most of the employees have a high degree of e-health literacy. The relevant employees of the county are familiar with e-health technology and have a positive attitude towards trying new e-health services ".

The authors of the present paper add to these findings a strategy noticed to strengthen the use of ICT in this region, corresponding to the category of new communications. This is 
the promotion and expansion of the "AC-Net" Internet Connection Network. This network corresponds to a very high-speed fiber optic internet connection with the aim of achieving a minimum connection speed of 100 megabits per second in at least $90 \%$ of homes in the region in 2020 (regionvasterbotten.se). The company installing this network was founded in 1996 by a public-private partnership including the Västerbotten region (Alrutz, 2007). The Västerbotten region claims to have the best internet connection network in Europe (regionvasterbotten.se). Despite the fact that this strategy is not aimed specifically at the elderly but at all the inhabitants of the region, the elderly can also benefit from it.

\section{Wielkopolska Region - Poland}

In Poland the responsibility for social care and healthcare policy development is shared between the state government, regions, counties and municipalities. The central government provides a political and legal framework for social policies; nonetheless the cost of their implementation is transferred to the municipal, county and regional governments. In Wielkopolska, according to Gluszak et al. (2011) two public strategies have been identified at the regional level (Table 4). Here we present their themes as well as their relevant contents.

Table 4. Synthesis of public strategies in Wielkopolska in Poland

\begin{tabular}{|c|c|c|c|c|}
\hline & Geographical & Location & Plan / Strategy title & Category \\
\hline 1 & Regional & $\begin{array}{c}\text { The whole } \\
\text { region }\end{array}$ & $\begin{array}{l}\text { Social policy strategy for the region } \\
\text { of Wielkopolska until 2020 }\end{array}$ & $\begin{array}{c}\text { Health safety \& New } \\
\text { communications }\end{array}$ \\
\cline { 1 - 1 } 2 & $\begin{array}{l}\text { E-Wielkopolska strategy : Building } \\
\text { and development of information } \\
\text { society in Wielkopolska }\end{array}$ & New communications \\
\hline
\end{tabular}

Social policy strategy for the Wielkopolska region until 2020

This document describes the main directions for the development and implementation of social policy in the region. As an integral part of Wielkopolska's regional development strategy up to 2020, it includes three guidelines on the use of ICT in the lives of older people.

«Priority 1: equal opportunities for seniors:

- supporting educational workshops aimed at introducing older people to the circulation of information in the information society (the priority is mastering new technologies to facilitate daily operations).

- to support projects that increase the availability of electronic monitoring of people reliant on staying at home and the development of volunteer resources, patron visits (the minimum: dissemination of electronic paging systems).

- expanding learning opportunities for seniors through: supporting educational programs for the elderly introducing them into the information society (priority: taming the new technologies to facilitate daily functioning). " 
Of the three measures identified, two address the training of older people in the use of ICTs. These are measures to support training workshops, both in the context of promoting "equal opportunities" in relation to other groups of citizens and, secondly, to prevent domestic accidents related to ICTs. The third measure addresses health safety at home through the installation of electronic monitoring and remote assistance systems.

\section{E-Wielkopolska Strategy}

This strategy's aim is to build and develop the information society in connection with the main strategic aims of the region. One provision particularly relates to the elderly: "The strategy for e-WIELKOPOLSKA highlights the low level of modern knowledge among the older generation as a weakness in its SWOT analysis and identifies it as a threat to social exclusion of the older generation " (Gluszac, Kosiedowski and Minkowski, 2011).

\section{Territory of Brescia (Italy) and North Hungary}

No public strategy document has been identified in these territories (Arenghi, Angelini \& Pucci, 2012; Gyorffy, Nagy \& Nandori, 2011).

\section{DISCUSSION}

\section{Summary of data}

In this study we looked at the existing regulations and strategies between 2011 and 2013 for the use of ICT-based home care services for the elderly in several European territories. Public policy practices have been compared across territories of seven European countries. We have sought to describe the similarities and differences between regions because of their specific initiatives and directions governing the relationship between supply and demand for ICT-based services to the elderly. The method was to compare the results obtained in each of the seven territories studied as part of the European project SILHOUETTE and written in reports available on its website. The formulation of the research questions, the analysis and the synthesis were done by us.

In the French Region, five public strategies have been identified. Our observation is that the French communities rely mainly on subsidizing acquisition of ICT-based solutions and training the elderly to the use of ICTs. Few actions and reflections are conducted within this territory on other possible strategies. In 2011, the movement towards reinforcing the use of ICT by / for the elderly has only started in Lorraine.

In Spain, local authorities in Asturias focus on three strategies: the training of older people to use ICTs, the development of telemedicine services and the use of ICTs by the elderly to avoid social isolation. 
The Finnish region is by far the one where the largest number of public policy documents from local authorities has been identified. Thirteen strategy documents including ICTs in the services for the elderly have been identified. Only one of these documents is a publication of the regional executive: "Kanta-Häme Wellness Strategy 2015". The others come from the municipalities and two of the three county executives existing in this region. We identified six topics in the local community orientations: (1) the well-being of the inhabitants, (2) municipal services, (3) municipal strategies for the care of the elderly, (4) departmental strategies for the care of the elderly, (5) municipally managed health care, and (6) dementia.

We find that the regional community provides global guidance for the use of ICTs to improve the comfort of older people without details. The documents from the counties indicate a willingness to be involved in different phases of implementation of ICT-based solutions, namely the development, deployment, distribution of solutions, as well as training in the use of ICTs. Counties are therefore stakeholders in research and development activities. The involved Counties are planning to develop new ICT-based solutions for use by stakeholders and / or the elderly themselves. This would be less about improving existing solutions than about operating innovation. Community services focus on the accessibility of municipal services to the elderly through ICTs, improving care, beneficiaries of welfare and staff working conditions through ICTs, and improving the quality of ICTs themselves by setting concrete goals.

In the Swedish region, most home care services already rely heavily on ICTs. A single strategy to strengthen the use of ICT in this region has been identified, corresponding to the category of new communications. This is the promotion and expansion of the "AC-Net" Internet Connection Network.

In Poland, local authorities are focusing their efforts on supporting training workshops for older people and strengthening home health safety through the installation of electronic monitoring and teleassistance systems. Finally, in Italy and Hungary we have found no public guidance in this area.

\section{Comparison of results between regions}

Comparing the different regions' strategies enlightens the close results found in France, Spain and Poland. Indeed, we note that in these three territories there are close orientations, pertaining to the training of older people in ICTs and the strengthening of health security through ICTs. The French Region is distinguished by a subsidy orientation and the Spanish region is distinguished by a specific orientation of social links through new modes of communication.

The Finnish region has a different profile from these three regions. This is due to a much larger presence of the topic of ICT-based home care for older people as well as more specific, more detailed guidance covering a wider range of situations and issues. Thus this region is the only one of the local authorities declaring to engage in research and development processes and giving quantified objectives in terms of implementation of the ICTs for different types of needs. 
Also, the Swedish region on the one hand and the Italian and Hungarian regions on the other, have two different profiles. The first one does not present a particular local strategy except the construction and the provision of a very high-speed internet network for people living in the most remote areas of this region. This region already uses many ICT-based solutions that are well established and used daily for home care of the elderly, suggesting the greatest level of development on this matter among all the territories included in the study. On the other hand, in the Italian and Hungarian regions we have not identified any public orientation on this subject or solution based on ICT.

From these results we can draw a table showing the integrated stages of development of strategic directions for ICT-based solutions in home care for the elderly (Table 5). The table ranks countries according to their development. The Nordic countries (Finland, Sweden) are the most advanced, France and Spain show a lesser but not insignificant development, while Italy, Hungary and Poland are the ones with the most delay in developing good practices of ICTs for the elderly. We recommend to all policymakers and local governments, not only of the regions and territories included in the present paper, to use this table to find out at which stage their policies are and what kind of measures they could implement to make progress.

Table 5. Stages of development of strategic directions for ICT-based solutions in home care

\begin{tabular}{|c|l|c|}
\hline Stage & Description & Concerned Region \\
\hline 0 & No public policy & Italian, Hungarian \\
\hline 1 & $\begin{array}{l}\text { Support for ICT training workshops and reinforcement of teleassistance } \\
\text { practices }\end{array}$ & Polish \\
\hline 2 & Stage 1 + subsidy reinforcement & French \\
\hline 3 & $\begin{array}{l}\text { Stage 2 + supporting the development of new communications to combat } \\
\text { isolation }\end{array}$ & Finish \\
\hline 4 & $\begin{array}{l}\text { Stage 3 + participation in research and development for a wider range of } \\
\text { needs }\end{array}$ & $\begin{array}{l}\text { Successful implementation of solutions and mastery of procedures to } \\
\text { support new solutions }\end{array}$ \\
\hline 5
\end{tabular}

\section{Comparisons between our results and the recommendations of the literature}

We compared these results to the 2010 European exploratory workshop's recommendations to assess and better understand the nature of the gaps between policy practices in each region and its recommendations. This comparison showed that the recommendations are included in the guidelines developed by the Finnish region. These were: (1) to identify available information and communication needs in relation to different use scenarios at the intersection of health and social services; (2) to develop and map shared ontologies and standards for integration and / or commercialization, (3) enable sharing and access to information, the development of a trusted system where the patient is an active partner and where policies are established by taking into account all partners and interests, 
(4) analyze the use of intelligent / automatic knowledge services relevant to context, and (5) empower citizens (or selected representatives) to become co-producers, using modern ICT tools, while carefully avoiding the marginalization of the most vulnerable. In the French region, one county has particularly included among its official goals an orientation incorporating the third recommendation. There is no other public strategy in this region or in another region taking up, if only partially, one of these recommendations. This is probably because these strategies do not focus on research and development of ICT-based solutions but rather on support, facilitation and promotion of existing solutions.

The organization and provision of long-term home care services for older people in the EU began to be studied by Riedel, Kraus and Mayer (2015). Based on national public policy documents from 2010, the organizational aspects of formal home care provision for people over 65 were compared to provide an understanding of the care access. Their study showed that: (1) the regulation of home care for the elderly was more centralized in the new EU member states from Eastern Europe than in the former member countries from Western Europe, (2) access to this type of service was not more restricted in Eastern European countries, in terms of resource and disability requirements and, (3) in the countries in Eastern Europe formal and regulated home care was less developed than in western and Scandinavian countries, the former being more accustomed to the alternative between institutional care and informal care by family caregivers.

In our study, one country from Eastern Europe presents relevant strategies: Poland. In terms of centralization, we found that this country gives local authorities the freedom to design territorial guidelines for the promotion and support of ICTs in home care for the elderly. From this point of view there is no difference with France for example. On the other hand, we note a qualitative difference between Finland on the one hand and Poland, France and Spain on the other, since, in 2011, the participation of political institutions in research and development appeared to be more decentralized in Finland, with broader objectives in terms of meeting needs such as improving home comfort and not just health security. These results do not suggest an East / West gap contrary to the results of Riedel, Kraus and Mayer (2015).

Regarding the guidelines on the conditions of access to ICT-based services, it seems to us that the Spanish orientation towards the development of new types of communications for social relations actually widens the public benefiting from these services since it is not necessarily a response to a need for medical surveillance, but to improve the well-being of the elderly person by creating or maintaining a social bond. Similarly, the Finnish local government guidelines show that there is a desire to bring ICT-based services to an older public that is much larger than the one requiring medical surveillance. In addition, the strategy for developing solutions for dementia situations shows the Finnish willingness to include any type of senior's profile in ICT-based home care development plans. Moreover, we found the elderly's participation in strategy design in only one document, from Hämeenlinna municipality senior citizen's advisory council (Finland). This is the only example, among all the strategies studied in the present paper, where the elderly participate to the strategy development process. This example shows that the elderly, especially their younger generations, can and should give their opinions in this field and that they are demanding and willing to take part in the development of ICT-based services. This should encourage policy makers to include them systematically in the design of strategies supposed to be at the service of their quality of life and empowerment. Finally, with regard to the development of 
regulations for ICT-based home services, we find that the most advanced countries are the Nordic countries: Sweden and Finland. It is these countries that have pushed their thinking and the commitment of their institutions to strengthen ICT-based solutions for older people. Consequently, our results suggest a North/South gap.

The results of this study therefore lead us to recommend to the different communities to follow the development stages of this type of solution described in Table 5 above. However, in light of our results, the recommendations of Abraham et al. (2011) are also relevant and should be integrated into the development plans for ICT-based solutions for home care. According to these authors the new guidelines to be developed would concern: (a) the training of ICT specialists within the medical community, (b) incentives for service providers, (c) legislation dealing with responsibilities, security, privacy and confidentiality, (d) the inclusion of stakeholders in the development of solutions, and (e) the creation of sustainable business models. We notice that these five recommendations have all been followed by local authorities in the Finnish region. As a matter of fact, we found at least one public orientation in line with each of these recommendations in the 13 public policy documents published in this region. On the other hand, in Italy, Hungary, Poland, France and Spain, we recommend that local authorities follow these recommendations by integrating these topics into their plans.

The access, through the present paper, to local and regional strategy documents from several EU member states gives also gerontechnologists a vision of how ICT-based solutions for the aging-in-place are actually being considered by policymakers at different levels and how strategies are planned in this geographical, political and economic framework. This is, in our opinion, a useful contribution to the gerontechnologists' thinking about the way these policy strategies are designed; the way they can be improved at all levels; and the role of the various stakeholders in this improvement, within the meaning of Stewart and Centeno (2012), including as well the elderly and the gerontechnologists.

\section{CONCLUSION}

In conclusion, in this study we have described and compared the public orientations and strategies implemented in 2011-2013, in seven European territories, to develop ICT-based home care services (in the sense of the OECD) for the elderly. Comparisons were first made between territories. This allowed us to understand the different stages of development of this sector of activity, which we have synthesized and to provide recommendations to policymakers. Then, we made a comparison between our results and the recommendations of the European exploratory workshop organized in 2010 on this theme under the auspices of the European Science Foundation.

It appears to us that these recommendations are generally followed in Finland by the local authorities whereas in the other territories the follow-up of these recommendations by the communities is either stammering or non-existent (Italy, Hungary). We also compared the SILHOUETTE's results with those obtained by Riedel, Kraus and Mayer (2015) based on 2010 national policy documents on home care services for seniors. We draw from this comparison the conclusion that in the context of ICT-based services the East / West comparison does not seem relevant. Offsets in terms of public orientations show much more a North / South shift. 
This is true of all three aspects studied by Riedel, Kraus and Mayer (2015): the distribution of policies and strategies between institutional levels, the strategies concerning accessibility to services and the regulation of the supply of services. Finally, we found that the recommendations made by Abraham et al. (2011) based on the study of the Japanese situation are also relevant in Europe and already existing in the concerns of the Nordic communities, namely in Sweden and Finland. We suggest gerontechnologists to include the present contribution to their thinking about future strategy design. The two main limitations of this study are the lack of comparison of national policies that would have allowed local policies to be put into perspective, as well as reliance on documents in effect in 2011-2013, although all the documents used had a validity date extending beyond that period.

\section{$\underline{\text { References }}$}

Arksey, H., \& Kemp, P. A. (2008), Dimensions of choice: a narrative review of cash-for-care schemes, Working Paper No. DHP 2250, York: University of York, Social Policy Research Unit.

Atarodi, S., Berardi, A. M., \& Pruski, A. (2012). Orientation des personnes âgées vers les technologies d'assistance en France : le cas de la région lorraine. Gérontologie et Société, $\mathrm{n}^{\circ} 141 \mathrm{pp} 13-26$.

Cartwright, M., Hirani, S.P., Rixon, L., Beynon, M., Doll, H., Bower, P., Bardsley, M., et al. (2013), “Effect of telehealth on quality of life and psychological outcomes over 12 months (Whole Systems Demonstrator telehealth questionnaire study): nested study of patient reported outcomes in a pragmatic, cluster randomised controlled trial.", BMJ (Clinical research ed.), Vol. 653 No. February, p. f653.

Cavallo, F., Pujol, L., Garcia, A., \& Dario, P. (2010). The AALIANCE research agenda on ICT for ageing well. Gerontechnology, 9(2):181-182

Coenen, L., Hansen, T., \& Rekers, J. V. (2015). Innovation Policy for Grand Challenges. An Economic Geography Perspective. Geography Compass, 9(9), 483-496.

Costa-Font, J. \& Courbage, C. (eds) (2012), Financing Long-Term Care in Europe: Institutions, Markets and Model, Basingstoke: Palgrave Macmillan.

Costa-Font, J., Wittenberg, R., Patxot, C., Comas-Herrera, A., Gori, C., Di Maio, A., Pickard, L., Pozzi, A., \& Rothgang, H. (2008). Projecting long-term care expenditure in four European Union member states: the influence of demographic scenarios. Social Indicators Research, 86(2), 303-21.

Damant, J. (2014). Older adults, e-inclusion and access to ICT-based care. PhD Thesis. The London School of Economics and Political Science.

Damant, J., Knapp, M., Watters, S., Freddolino, P. \& Ellis, M. (2013). The impact of ICT services on perceptions of the quality of life of older people. Journal of Assistive Technologies, Vol. 7 No. 1, pp. 521. 
Da Roit, B. \& Le Bihan, B. (2010). Similar and yet so different: cash-for-care in six European countries' long-term care policies. The Milbank Quarterly, 88,3: 286-309.

Da Roit, B., Le Bihan, B. \& Österle, A. (2007). Long-termcare policies in Italy, Austria and France: variations in cash-for-care schemes. Social Policy \& Administration, 41, 6: 653-71.

European Commission (2011). How to promote active ageing in Europe - EU support to local and regional actors. Brussels: EU.

European Commission. (2012). eHealth Action Plan 2012-2020 - Innovative healthcare for the 21st century. COM 736 final. Brussels: European Commission.

Fernandez, J. L., Forder, J., Trukeschitz, B., Rokosova, M. \& McDaid, D. (2009). How Can European States Design Efficient, Equitable and Sustainable Funding Systems for Long-Term Care for Older People? Policy Brief, Copenhagen: World Health Organization, Regional Office for Europe and European Observatory on Health Systems and Policies.

Fundacion CTIC - Technology Center. (2011). ICT-based Support for the Elderly in Asturias: Strategies, Policies and Good Practices. Work report. SILHOUETTE project.

Giannakouris, K. (2008). Ageing characterises the demographic perspectives of the European societies. Statistics in Focus, 72.

Le Bihan, B. \& Martin, C. (2006). A comparative case study of care systems towards frail elderly people: Germany, Spain, France, Italy, United Kingdom, Sweden. Social Policy \& Administration, 40, 1: 26-46.

Le Goff-Pronost, M., \& Picard, R. (2011). Need for ICTs assessment in the health sector: a multidimensional framework. Communications \& Strategies, 1(83), 87-108.

Glendinning, C. \& Moran, N. (2009). Reforming Long-term Care: Recent Lessons from Other Countries, Working Paper No. DHP 2318, York: University of York, Social Policy Research Unit.

Gorman, J., Mikalsen, M., Stav, E., \& Walderhaug, S. (2010). universAAL - European Commission collaborative research and development to develop an open architecture and platform for Ambient Assisted Living (AAL). Gerontechnology; 9(2):183-184.

Gluszak, B., Kosiedowski, M., \& Minkowski, A. (2011). ICT-based Support for the Elderly in Wielkopolska: Strategies, Policies and Good Practices. Work report. SILHOUETTE project.

Gyorffy, I., Nagy, Z. \& Nandori, E. (2011). ICT-based Support for the Elderly in North-Hungary: Strategies, Policies and Good Practices. Work report. SILHOUETTE project.

Karlsson, M., Mayhew, L. \& Rickayzen, B. (2007). Long term care financing in four OECD countries: fiscal burden and distributive effects. Health Policy, 80, 1:107-34.

Knapp, R.B., Coghlan, N., Caulfield, B., Bennis, C., Pavel, M., Jimison, H., King, R., Hashimoto, S., Enriquez, W., Mcgrath, M., Dalton, J., Dishongh, T., Bonato, P., Camurri, A., B., Volpe, G., \& 
Ivan, P. (2010). The CAPSIL project: Creating a strategy for ICT and ageing across Japan, the EU, and the US. Gerontechnology; 9(2)182-183.

Olsson, S. (2010). Ambient Assisted Living Joint Program: A European wide initiative. Gerontechnology, 9(2):182.

Organisation for Economic Co-operation and Development (OECD) (2005). Ensuring Quality Long-Term Care for Older People, Paris: OECD.

Österle, A. (2010), Long-term care in Central and South-Eastern Europe: challenges and perspectives in addressing a 'new' social risk. Social Policy \& Administration, 44(4), 461-80.

Pavolini, E., \& Ranci, C. (2008), Restructuring the welfare state: reforms in long-term care in Western European countries. Journal of European Social Policy, 18(3), 246-59.

Piironen, J. (2011). ICT-based Support for the Elderly in Kanta-Häme: Strategies, Policies and Good Practices. Work report. SILHOUETTE project.

Riedel, M., Kraus, M., \& Mayer, S. (2015). Organization and Supply of Long-term Care Services for the Elderly: A Bird's-eye View of Old and New EU Member States. Social Policy \& Administration, 50(7), 824-845.

Rigby, M., Hill, P., Koch, S., \& Keeling, D. (2011). Social care informatics as an essential part of holistic healthcare: A call for action. International Journal of Medical Informatics, 80, 544-554.

Rostgaard, T. (2011). LIVEINDHOME, Living independently at home, Copenhagen: SFI - The Danish National Centre for Social Research.

Simonazzi, A. (2012). Time, cash and services: reforms for a future sustainable long-term care. Futures, 44, 7: 687-95.

Stewart, J. \& Centeno, C. (2012). ICT-enabled services for carers and care: Lessons for policy and innovation. Gerontechnology; 11(2):395.

Timonen, V., Convery, J. \& Cahill, S. (2006). Care revolutions in the making? A comparison of cash-for-care programmes in four European countries. Ageing \& Society, 26, 3: 455-74.

Vimarlund,V., \& Olve, N. G. (2005). Economic analysis for ICT in elderly healthcare : questions and challenges. Health Informatic Journal, 11(4), 309-21.

Vosges' County council. (2009). Schéma départemental Handicap et dépendance tout au long des âges de la vie 2009-2013.

Wintlev-Jensen, P. (2010). Key European research and innovation initiatives: Addressing new technologies and services for ageing well. Gerontechnology, 9(2):180. 
